\title{
INDUKCIÓS GÉPEK ROTORFLUXUSÁNAK AZONOSÍTÁSA CSÚSZÓMÓD ÁLLAPOTMEGFIGYELŐVEL
}

\section{INDUCTION MACHINE ROTOR FLUX IDENTIFICATION USING SLIDING MODE OBSERVER}

\author{
Kacsó Zoltán ${ }^{1}$, Kelemen András ${ }^{2}$, Imecs Mária ${ }^{3}$ \\ ${ }^{1,2}$ Sapientia EMTE, Müszaki és Humántudományok Kar, Villamosmérnöki Tanszék, \\ Románia, Koronka, 1/C, Telefon: +40-748-506619, \\ ${ }^{1}$ kacsozoli82@yahoo.com, ${ }^{2}$ kandras@ms.sapientia.ro \\ ${ }^{3}$ Kolozsvári Müszaki Egyetem, Villamosmérnöki Kar, Villamos Gépek és Hajtások \\ Tanszék, Románia, Kolozsvár, Telefon: +40-741-044-208, \\ maria.imecs@emd.utcluj.ro
}

\begin{abstract}
The paper presents theoretical details and Matlab-Simulink ${ }^{\circledR}$ based simulation of the direct fieldoriented control of the squirrel-cage induction machine using sliding-mode flux estimation. The flux estimation is based on a state-space model in which the state vector is formed by the components of the stator current and of the rotor flux. The measured angular speed is a parameter of the system matrix. The theoretical background of the paper is based on the work of Picardi and Scibilia. The sliding control is made using the sign of the stator-current estimation error. Different flux estimation methods have been demonstrated by simulation.
\end{abstract}

Keywords: induction motor, field orientation, flux identification, sliding-mode observer.

\section{Összefoglalás}

A dolgozat rövidrezárt forgórészű indukciós gépek rotorfluxusának azonosítását tárgyalja a direkt mezőorientációs szabályozási struktúra megvalósításának céljából. A rotor feszültségegyenletén alapuló, klasszikusnak tekinthető fluxusazonosító vonatkoztatási alapként szolgál a dolgozatban szereplő csúszómód-fluxusazonosító ismertetéséhez, amelynek elméleti hátterét a szakirodalomból merítettük. A csúszómód-állapotmegfigyelő a gép olyan matematikai modelljére támaszkodik, amelynek állapotváltozói a sztátoráram és a rotorfluxus összetevői, míg a rotor mért szögsebessége a modell egyik paramétere. A csúszómód a sztátoráram-összetevők méréssel meghatározott értékei körül jön létre, míg a visszacsatolt mennyiségek a sztátoráram-összetevők becslési hibáinak előjelei. A direkt mezőorientációs szabályozási struktúrával ellátott hajtás és az alegységként beépített csúszómód-fluxusazonosító müködésének szimulációját Matlab-Simulink ${ }^{\circledR}$ környezetben végeztük.

Kulcsszavak: indukciós motor, mezőorientáció, fluxusazonositás, csúszómód-állapotmegfigyelö.

\section{Bevezető}

Az indukciós gép mezőorientációs szabályozása lehetővé teszi irányítási szem- pontból az egyenáramú hajtásokéhoz hasonló minőségi mutatók elérését. A rotormezőorientáció esetében az elektromágneses nyomaték és a fluxus szabályozása a rotorfluxushoz rögzített, vele együtt forgó 
koordináta-rendszerben történik. Ehhez direkt, vagy indirekt módon - szükséges a rotorfluxusvektor pozíciójának és nagyságának ismerete. A fluxus mérése nem járható út, így meghatározására matematikai modell alapján, állapotmegfigyelő segítségével kerül sor. Ennek típusai folyamatos kutatás tárgyát képezik, mivel az indukciós gép viszonylag bonyolult viselkedése irányítástechnikai szempontból is kihívást jelent.

A dolgozatban egy célszerüen felépített matematikai modellt felhasználó csúszómód-állapotmegfigyelöt mutatunk be. Ennek elméleti hátterét a Picardi és Scibilia által közölt munkára alapoztuk [1].

\section{Az indukciós gép állapotteres modellje}

Az alábbiakban az indukciós gép állapotteres modelljét a csúszómódállapotbecslő alkalmazásához előnyös formában fogalmazzuk meg, úgy, hogy a sztátoráram és a rotorfluxus összetevői képezzék az állapotvektort.

$\mathrm{Az}$ indukciós gép úgynevezett általános egyenleteiből a rotor térfazoros feszültségegyenlete a sztátorhoz rögzített koordinátarendszerben [2], [3]:

$$
R_{r} \underline{i}_{r}+\frac{d \underline{\Psi}_{r}}{d t}-\underline{j} \omega_{e} \underline{\Psi}_{r}=0,
$$

ahol $\omega_{e}$ a forgórész szögsebessége elektromos szögben mérve, melyet a rotor $\omega_{r}$ mechanikai szögsebessége függvényé-ben az $\omega_{e}=z_{p} \omega_{r}$ összefüggés adja, ahol $z_{p}$ a gép póluspárainak a száma.

A rotor fluxusegyenlete

$$
\underline{\Psi_{r}}=\left(L_{m}+L_{\sigma r}\right) \underline{i_{r}}+L_{m} \underline{i_{s}}
$$

alapján kifejezzük a rotoráramot:

$$
i_{r}=\frac{1}{L_{r}} \underline{\Psi_{r}}-\frac{L_{m}}{\left(L_{m}+L_{\sigma r}\right)} i_{s}
$$

melyet az (1) feszültségegyenletbe helyettesítve a rotorfluxus deriváltja kifejezhető:

$$
\frac{d \Psi_{r}}{d t}=-\frac{R_{r}}{L_{r}} \underline{\Psi_{r}}+R_{r} \frac{L_{m}}{L_{r}} i_{s}+\underline{j} \omega_{e} \underline{\Psi_{r}},
$$

(4)

illetve összetevőkre bontva skaláris formában:

$$
\left\{\begin{array}{l}
\frac{d \Psi_{r d}}{d t}+\frac{R_{r}}{L_{r}} \Psi_{r d}+\omega_{e} \Psi_{r q}-L_{m} \frac{R_{r}}{L_{r}} i_{s d}=0 \\
\frac{d \Psi_{r q}}{d t}+\frac{R_{r}}{L_{r}} \Psi_{r q}-\omega_{e} \Psi_{r d}-L_{m} \frac{R_{r}}{L_{r}} i_{s q}=0
\end{array}\right.
$$

A sztátorfluxust is a sztátoráram és a rotorfluxus függvényében fejezzük ki:

$$
\underline{\Psi_{s}}=\left(L_{m}+L_{\sigma \vec{\sigma}}\right) \underline{i_{s}}+L_{m} i_{\underline{r}}=L i_{\underline{s}}+\frac{L_{m}}{L_{r}} \underline{\Psi_{r}}
$$

ahol

$$
L=\frac{\left(L_{\alpha s}+L_{\sigma r}\right) L_{m}+L_{\alpha s} L_{\sigma r}}{L_{\sigma r}+L_{m}}, \quad L_{r}=L_{\sigma r}+L_{m}
$$

A sztátor feszültségegyenlete a sztátorhoz rögzített koordináta-rendszerben

$$
\underline{u_{s}}=R_{s} i_{s}+\frac{d \underline{\Psi_{s}}}{d t}
$$

a sztátoráram és a rotorfluxus állapotváltozók függvényében a következőképpen alakul:

$$
\begin{aligned}
& \underline{u_{s}}=R_{s} i_{s}+L \frac{d \underline{i_{s}}}{d t}+ \\
& +\frac{L_{m}}{L_{r}}\left(-\frac{R_{r}}{L_{r}} \underline{\Psi_{r}}+R_{r} \frac{L_{m}}{L_{r}} \underline{i}_{s}+j \omega_{e} \underline{\Psi_{r}}\right)
\end{aligned}
$$

A (4) és (7) egyenletekből közvetlenül származtatható az indukciós gép modellje állapotteres formában, vektoriális 


$$
\left\{\begin{array}{l}
\frac{d \underline{i_{s}}}{d t}=-\frac{1}{L}\left(R_{s}+R_{r}\left(\frac{L_{m}}{L_{r}}\right)^{2}\right) i_{s}+ \\
+\frac{L_{m}}{L L_{r}}\left(\frac{R_{r}}{L_{r}}-j \omega_{e}\right) \Psi_{r}+\frac{1}{L} \underline{u_{s}} \\
\frac{d \underline{\Psi_{r}}}{d t}=L_{m} \frac{R_{r}}{L_{r}} i_{s}-\left(\frac{R_{r}}{L_{r}}-j \omega_{e}\right) \underline{\Psi_{r}}
\end{array}\right.
$$

illetve skaláris (9) egyenletekkel felírva.

$$
\left\{\begin{array}{l}
\frac{d i_{s d}}{d t}=-\frac{1}{L}\left(R_{s}+R_{r}\left(\frac{L_{m}}{L_{r}}\right)^{2}\right) i_{s d}+ \\
+\frac{L_{m} R_{r}}{L L_{r}^{2}} \Psi_{r d}+\frac{L_{m}}{L L_{r}} \omega_{e} \Psi_{r q}+\frac{1}{L} u_{s d} \\
\frac{d i_{s q}}{d t}=-\frac{1}{L}\left(R_{s}+R_{r}\left(\frac{L_{m}}{L_{r}}\right)^{2}\right) i_{s q}- \\
-\frac{L_{m}}{L L_{r}} \omega_{e} \Psi_{r d}+\frac{L_{m} R_{r}}{L L_{r}^{2}} \Psi_{r q}+\frac{1}{L} u_{s q} \\
\frac{d \Psi_{r d}}{d t}=L_{m} \frac{R_{r}}{L_{r}} i_{s d}-\frac{R_{r}}{L_{r}} \Psi_{r d}-\omega_{e} \Psi_{r q} \\
\frac{d \Psi_{r q}}{d t}=L_{m} \frac{R_{r}}{L_{r}} i_{s q}+\omega_{e} \Psi_{r d}-\frac{R_{r}}{L_{r}} \Psi_{r q}
\end{array}\right.
$$

A (9) egyenletrendszerben az $\omega_{e}$ szögsebesség paraméter, melynek a fluxusazonosítás során felhasznált pillanatértékét mérés útján határozzuk meg.

$\mathrm{Az}$ állapotváltozók vektora

$$
\mathbf{x}=\left[\begin{array}{llll}
i_{s d} & i_{s q} & \Psi_{r d} & \Psi_{r q}
\end{array}\right]^{T},
$$

a mérhető mennyiségek vektora

$$
\mathbf{y}=\left[\begin{array}{ll}
i_{s d} & i_{s q}
\end{array}\right]^{T} \text {, }
$$

a bemenetek vektora

$$
\mathbf{u}=\left[u_{s d} u_{s q}\right]^{T},
$$

segítségével tehát a (9) rendszer az alábbi jól ismert kanonikus formára hozható:

$$
\begin{aligned}
& \dot{\mathbf{x}}=\mathbf{A x}+\mathbf{B u}, \mathbf{y}=\mathbf{C x}, \\
& \text { ahol }
\end{aligned}
$$

$$
\mathbf{A}=\left[\begin{array}{cccc}
-\frac{1}{L}\left(R_{s}+R_{r}\left(\frac{L_{m}}{L_{r}}\right)^{2}\right) & 0 & \frac{L_{m} R_{r}}{L L_{r}^{2}} & \frac{L_{m}}{L L_{r}} \omega_{e} \\
0 & -\frac{1}{L}\left(R_{s}+R_{r}\left(\frac{L_{m}}{L_{r}}\right)^{2}\right) & -\frac{L_{m}}{L L_{r}} \omega_{e} & \frac{L_{m} R_{r}}{L L_{r}^{2}} \\
L_{m} \frac{R_{r}}{L_{r}} & 0 & -\frac{R_{r}}{L_{r}} & -\omega_{e} \\
0 & L_{m} \frac{R_{r}}{L_{r}} & \omega_{e} & -\frac{R_{r}}{L_{r}}
\end{array}\right]
$$

$$
\mathbf{B}=\left[\begin{array}{cc}
\frac{1}{L} & 0 \\
0 & \frac{1}{L} \\
0 & 0 \\
0 & 0
\end{array}\right] \text { és } \mathbf{C}^{T}=\left[\begin{array}{ll}
1 & 0 \\
0 & 1 \\
0 & 0 \\
0 & 0
\end{array}\right] .(11)
$$

Megfigyelhető, hogy az A mátrix a gép paraméterein kívül a szögsebességtől is függ. Míg az eredetileg [1] által javasolt csúszómód-állapotmegfigyelő a rotorsebesség azonosítására is alkalmas, dolgozatunk a rotorfluxus csúszómódidentifikációjának elméleti hátterét és Matlab-Simulink ${ }^{\circledR}$ szimulációját mutatja be.

\section{A rotorfluxus azonosítása csú- szómód-állapotmegfigyelővel}

A (10) rendszer állapotainak megfigyelése nyílt hurokban is elképzelhető az

$$
\dot{\hat{\mathbf{x}}}=\mathbf{A} \hat{\mathbf{x}}+\mathbf{B u}
$$

összefüggés szerint, ahol $\hat{\mathbf{x}}$ a becsült állapotok vektora.

Az $\widetilde{\mathbf{x}}=\hat{\mathbf{x}}-\mathbf{x}$ állapotbecslési hiba az A rendszermátrix által meghatározott dinamikával nullához tart, ha $\mathbf{A}$ aszimptotikusan stabil [4].

A becslés dinamikája megtervezhetö, ha a kimenetek $\mathbf{e}=\mathbf{C} \widetilde{\mathbf{x}}$ becslési hibáját viszszacsatoljuk.

Ezen az elven, a Luenberger típusú állapotmegfigyelő az alábbi összefüggés szerint müködik: 


$$
\dot{\hat{\mathbf{x}}}=\mathbf{A} \hat{\mathbf{x}}+\mathbf{B u}+\mathbf{L e}
$$

A becslési hiba visszacsatolása a csúszómód szabályozókra jellemző módon is kezelhető. Csúszómód szabályozók egyik lehetséges megvalósítása a vezérlőjel szintjén alkalmaz változó struktúrát, vagyis a vezérlőjelet az

$$
s(\mathbf{x})=-\mathbf{K}_{s} \mathbf{x}+\mathbf{K}_{w} \mathbf{w}
$$

összefüggés előjele határozza meg, ahol $s(\mathbf{x})$ az úgynevezett csúszófelület és $\mathbf{w}$ az elöírt állapotvektor.

Legyen az állapotvektor becslési hibája:

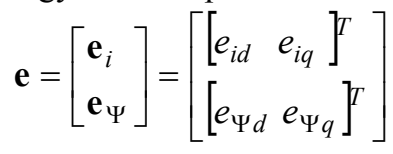

Ha a (10) rendszer $\mathbf{x}$ állapotvektora képviseli a (14) összefüggésben az állapotreferenciát, míg ennek az $\hat{\mathbf{x}}$ becsült értéke képviseli a (14) rendszer állapot-vektorát, illetve $\mathbf{K}_{s}=\mathbf{K}_{w}=-\mathbf{C}$, az $s(\hat{\mathbf{x}})$ elöjelét $\mathbf{e}_{i}=\mathbf{C} \hat{\mathbf{x}}-\mathbf{C x}$ előjele, vagyis a sztátoráram becslési hibájának előjele adja.

A (13) összefüggés utolsó tagját a $\mathbf{K} \operatorname{sgn}\left(\mathbf{e}_{i}\right)$ kifejezéssel helyettesítve, eredményül az alábbi csúszómód-állapotmegfigyelöt kapjuk:

$$
\dot{\hat{\mathbf{x}}}=\mathbf{A} \hat{\mathbf{x}}+\mathbf{B u}+\mathbf{K} \operatorname{sgn}\left(\mathbf{e}_{i}\right)
$$

Mivel a (10) rendszer esetében a mérhető kimenetek között csak a sztátoráram öszszetevői szerepelnek, belátható, hogy a csúszófelületeket tulajdonképpen az áramkomponensek becslési hibái határozzák meg.

A (10) és (16) összefüggésekből az állapotvektor becslési hibájának dinamikájára az alábbi egyenlet adódik:

$$
\dot{\mathbf{e}}=\mathbf{A e}+\mathbf{K} \operatorname{sgn}\left(\mathbf{e}_{i}\right)
$$

Ez a rendszer célszerüen módosítható úgy, hogy a csúszómód-állapotmegfigyelö (16) egyenletének jobb oldalán a becsült $\hat{\mathbf{x}}$ állapotvektort olyan

$$
\hat{\mathbf{x}}_{1}=\left\lfloor i_{s d} i_{s q} \hat{\Psi}_{r d} \hat{\Psi}_{r q}\right\rfloor
$$

állapotvektorral helyettesítjük, amelyben a mérhetó állapotoknak (a sztátoráram összetevőinek) már a mért értéke szerepel [1], vagyis:

$$
\dot{\hat{\mathbf{x}}}=\mathbf{A} \hat{\mathbf{x}}_{1}+\mathbf{B u}+\mathbf{K} \operatorname{sgn}\left(\mathbf{e}_{i}\right)
$$

$\mathrm{Ha}$ az

$$
\mathbf{A}=\left[\begin{array}{ll}
\mathbf{A}_{11} & \mathbf{A}_{12} \\
\mathbf{A}_{21} & \mathbf{A}_{22}
\end{array}\right]
$$

mátrixot 2x2-es méretü almátrixokra osztjuk, akkor az alábbi eredményre jutunk:

$$
\mathbf{A} \hat{\mathbf{x}}_{1}=\left[\begin{array}{l}
\mathbf{A}_{11} \\
\mathbf{A}_{21}
\end{array}\right]\left[\begin{array}{l}
i_{s d} \\
i_{s q}
\end{array}\right]+\left[\begin{array}{l}
\mathbf{A}_{12} \\
\mathbf{A}_{22}
\end{array}\right]\left[\begin{array}{l}
\hat{\Psi}_{s d} \\
\hat{\Psi}_{s q}
\end{array}\right]
$$

A (17) az alábbi formát ölti:

$$
\dot{\mathbf{e}}=\left[\begin{array}{l}
\mathbf{A}_{12} \\
\mathbf{A}_{22}
\end{array}\right] \mathbf{e}_{\Psi}+\mathbf{K} \operatorname{sgn}\left(\mathbf{e}_{i}\right)
$$

A feladat a $\mathbf{K}$ erősítési mátrix meghatározása úgy, hogy az állapotvektor becslési hibáját nullába vigye. Erre az egyik lehetőség a Lyapunov-módszer alapján történő, [1]-ben is alkalmazott szabályozó-tervezés.

Bár a Lyapunov-módszer szerinti tervezés általában lassú csúszómód-szabályozót eredményez [5], a dolgozatban ezt használjuk a csúszómód-állapotmegfigyelés elvének bemutatására.

A módszer lényege az, hogy keressünk olyan erősítési mátrixot, amelyre egy szimmetrikus, pozitív definit $\mathbf{P}$ mátrix segítségével meghatározott $V=\frac{1}{2}\left(\mathbf{e}^{T} \mathbf{P e}\right)$ pozitív függvény a nullához tart (idő szerinti deriváltja negatív). Ekkor ez a hibavektor nullához tart.

Az [1] szerint célszerü a (20) rendszert két alrendszerre bontani:

$$
\begin{aligned}
& \dot{\mathbf{e}}_{i}=\mathbf{A}_{12} \mathbf{e}_{\Psi}+\mathbf{K}_{1} \operatorname{sgn}\left(\mathbf{e}_{i}\right) \\
& \dot{\mathbf{e}}_{\Psi}=\mathbf{A}_{22} \mathbf{e}_{\Psi}+\mathbf{K}_{2} \operatorname{sgn}\left(\mathbf{e}_{i}\right)
\end{aligned}
$$

amelyek közül csak a (21)-re alkalmazzuk a Lyapunov-módszert a $\mathbf{K}_{1}$ erősítési 
mátrix meghatározására, és Lyapunovfüggvény jelöltként az egyszerü

$$
V=\frac{1}{2}\left(\mathbf{e}_{i}^{T} \mathbf{e}_{i}\right)
$$

pozitív függvényt használjuk.

A csúszómódban így nullára szabályozott $\mathbf{e}_{i}$ áramhiba esetén található olyan $\mathbf{K}_{2}$ erősítési mátrix, amely a fluxushibát is nullára szabályozza.

A $\quad \mathbf{K}_{1}=\left[\begin{array}{ll}k & 0 \\ 0 & k\end{array}\right]$ mátrixot átlós formában keressük úgy, hogy a (23) Lyapunovfüggvény jelölt idő szerinti deriváltja negatív legyen:

$$
\begin{aligned}
& \frac{d V}{d t}=\frac{d}{d t}\left(\frac{1}{2} \mathbf{e}_{i}^{T} \mathbf{e}_{i}\right)=\frac{1}{2}\left(\dot{\mathbf{e}}_{i}^{T} \mathbf{e}_{i}+\mathbf{e}_{i}^{T} \dot{\mathbf{e}}_{i}\right)= \\
& =\mathbf{e}_{i}^{T} \dot{\mathbf{e}}_{i}=\mathbf{e}_{i}^{T}\left(\mathbf{A}_{12} \mathbf{e}_{\Psi}+\mathbf{K}_{1} \operatorname{sgn}\left(\mathbf{e}_{i}\right)\right)
\end{aligned}
$$$$
\text { (24) }
$$

Tehát $\frac{d V}{d t}<0$, ha $k<0$ és

$$
|k|>\left|\frac{L_{m}}{L L_{r}}\left(\frac{R_{r}}{L_{r}} e_{\Psi r d}+\omega_{e} e_{\Psi r q}\right)\right|,
$$

illetve

$$
|k|>\left|\frac{L_{m}}{L L_{r}}\left(\frac{R_{r}}{L_{r}} e_{\Psi r q}-\omega_{e} e_{\Psi r d}\right)\right|,
$$

ami teljesíthetö, ha figyelembe vesszük a gép valós müködési feltételeit.

Csúszómódban az $u_{e q}$ ekvivalens vezérlöjel az $\dot{\mathbf{e}}_{i}=0$ feltételt valósítja meg, tehát [1]:

$$
0=\mathbf{A}_{12} \mathbf{e}_{\Psi}+\mathbf{K}_{1} u_{e q},
$$

amiből következik:

$$
u_{e q}=-\mathbf{K}_{1}^{-1} \mathbf{A}_{12} \mathbf{e}_{\Psi} \text {. }
$$

A (22) alrendszert ezzel a $\operatorname{sgn}\left(\mathbf{e}_{i}\right)=u_{e q}$ ekvivalens vezérlőjellel vezérelve a becsült rotorfluxus dinamikáját az alábbi egyenlet írja le:

$$
\dot{\mathbf{e}}_{\Psi}=\mathbf{A}_{22} \mathbf{e}_{\Psi}-\mathbf{K}_{2} \mathbf{K}_{1}^{-1} \mathbf{A}_{12} \mathbf{e}_{\Psi},
$$

ahonnan $\mathbf{K}_{2}$ meghatározható úgy, hogy teljesüljön az $\mathbf{A}_{22}-\mathbf{K}_{2} \mathbf{K}_{1}^{-1} \mathbf{A}_{12}<0$ feltétel, ami biztosítja azt, hogy a fluxushiba tartson nullához.

\section{Szimulációs eredmények}

A dolgozatban bemutatott fluxusazonosítási algoritmusokat MatlabSimulink $^{\circledR}$ környezetben végzett modellezéssel és szimulációval tanulmányoztuk.

$\mathrm{Az}$ 1. ábrán látható tömbvázlat $\mathrm{az}$ indukciós motor a klasszikusnak nevezhető direkt (közvetlen) rotormezö-orientációs szabályozási struktúráját mutatja be, ahol a feszültséginverter vezérelése áramvisszacsatolásos hiszterézises szabályozókkal kivitelezett impulzusszélesség-modulációs (ISzM) módszerrel történik, ami nagymértékben leegyszerüsíti a szabályozáshoz szükséges alapjelek számolását.

$\mathrm{Az}[\mathrm{A}]^{-1}$ és $\left[\mathrm{D}\left(-\lambda_{\mathrm{r}}\right)\right]$ mátrixoperátorokkal jelölt tömbök az inverz fázis-, illetve koordináta-transzformációt végzik el. A két transzformáció összevonva az inverz Parktranszformációnak felelnek meg, mely a három állórész-áram alapjelét generálja [2], [3]. 


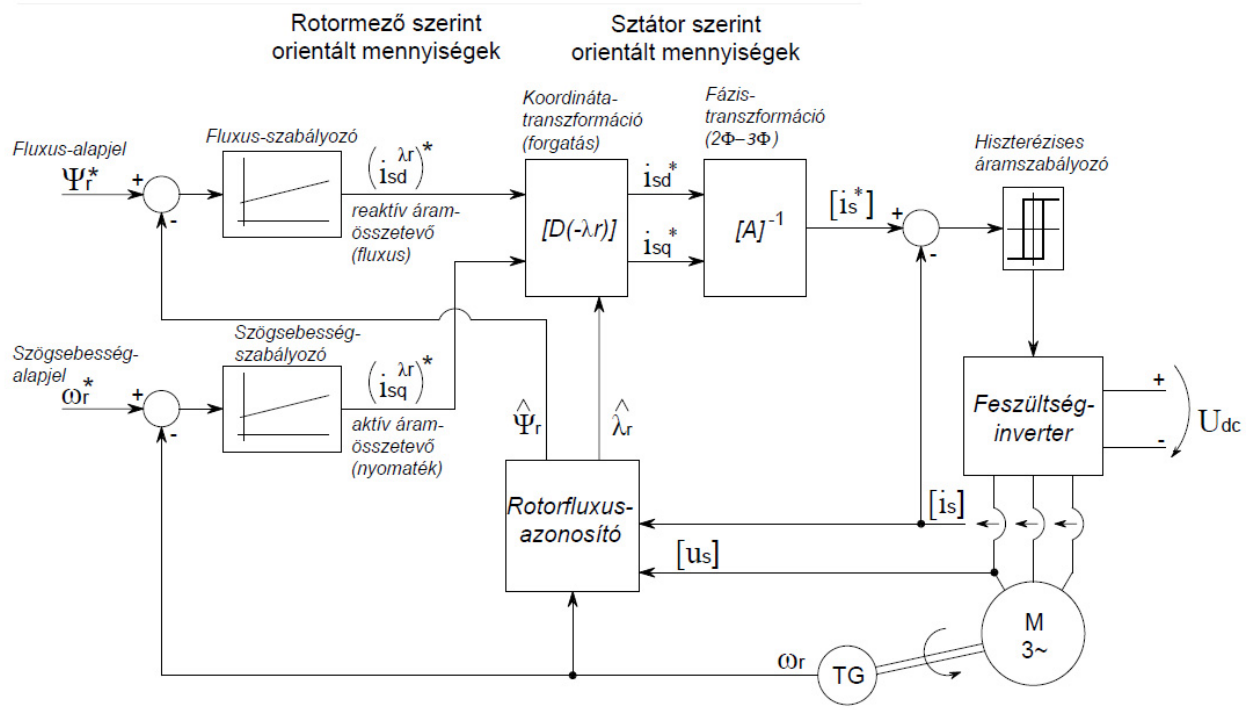

1. ábra. A rotorfluxus-azonositó tömb helye az indukciós gép direkt mezöorientációs szabályozási struktúrájában

A $\lambda_{\mathrm{r}}$ a rotorfluxus térfázorának a poziciószöge, és a rotorfluxus szerinti mezőorientált mennyiségeket jelöli.

A felépített modellben az indukciós gép paraméterei: $z_{p}=1$,

$$
\begin{aligned}
& R_{s}=R_{r}=0.816[\Omega], L_{m}=69[\mathrm{mH}], \\
& L_{\sigma s}=L_{\sigma r}=2[\mathrm{mH}], J=0.05\left[\mathrm{kgm}^{2}\right]
\end{aligned} .
$$

$\mathrm{Az}$ indítási szekvencia előmágnesezési eljárást tartalmaz, amelynek célja az alapjelnek megfelelő $\Psi_{r}=0.6[\mathrm{~Wb}]$ nagyságú rotorfluxus létrehozása a nyomatékszabályozás elkezdése előtt.

A 2. ábra a fluxusidentifikáció különböző megvalósításainak eredményét szemlélteti.

A klasszikusnak tekinthetö, a rotor feszültségegyenletéből (az úgynevezett „árammodell”) természetes kezdeti feltételekkel kiinduló fluxusazonosítás eredményét (itt a fluxus modulusát vizsgáljuk) tekintettük vonatkoztatási alapnak.

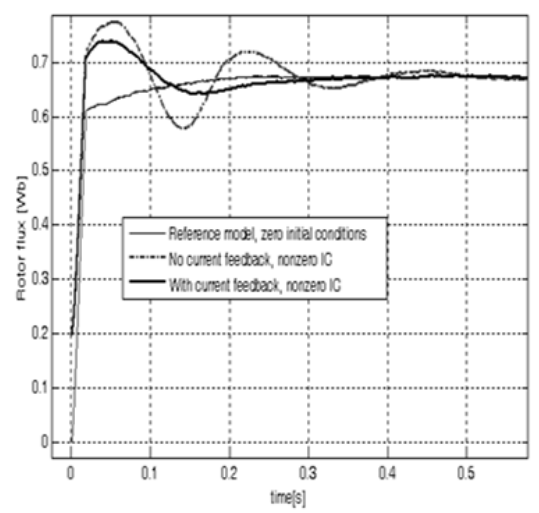

2. ábra. A rotorfluxus-modulus azonositásának eredménye a motor inditása során különbözö modellek, kezdeti feltételek és visszacsatolt mennyiségek felhasználása esetén

Ezzel összehasonlítva az ábrán megfigyelhető a (9) modell szerint nyílt hurokban történő (itt az áramvisszacsatolás szempontjából van szó nyílt hurokról; a rotor szögsebességét visszacsatoltuk, mivel a rendszermátrixban paraméterként szerepel), illetve a 
mért sztátoráram vissza-csatolásával történő fluxusidentifikáció eredménye. Mindkettő esetében a fluxus eröltetett kezdeti értékböl indul (a valós kezdeti fluxus nulla, míg az identifikáció során használt kezdeti feltétel $\left.\Psi_{r d}(0)=0.2[\mathrm{~Wb}], \Psi_{r q}(0)=0[\mathrm{~Wb}]\right)$.

A 3. ábra a rotorfluxus csúszómódidentifikációjának az eredményét mutatja az indítás és állandósult állapot során.
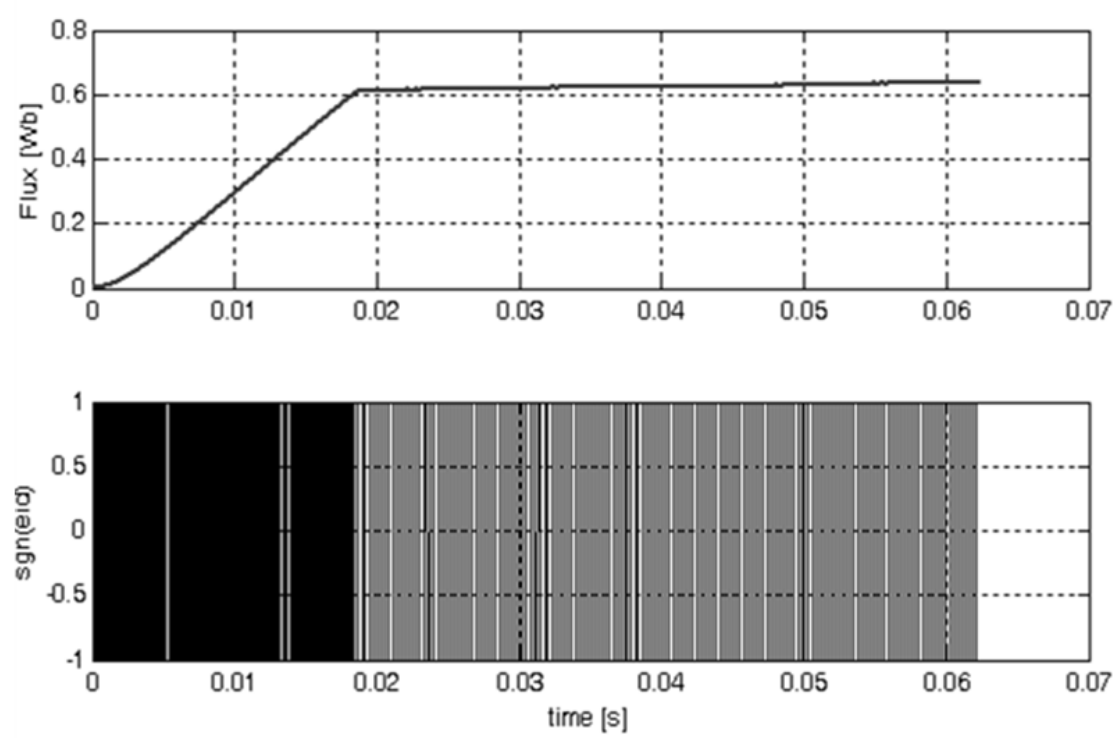

3. ábra. A rotorfluxus csúszómód-azonositásának szimulációs eredménye: a felsö diagram a sebesség időbeli változása, az alsó a „d” áramhiba összetevö elöjelének időbeli változását mutatja

A felső idődiagram a sebesség felfutását mutatja, míg az alsó a „d” fluxusképző áramösszetevö-hiba elöjelének a változását szemlélteti a csúszómód-becslés folyamán.

\section{Következtetések és további cél- kitüzések}

A dolgozatban bemutatott tanulmány egy lépés a szerzők azon törekvésében, amely a szakirodalomból ismert állapot- és paraméterbecslési eljárások alkalmazását célozza az indukciós gépek mezőorientált szabályozásában.

A továbbiakban a csúszómódállapotmegfigyelőt póluselhelyezéssel kívánjuk megtervezni. Célkitüzéseink között szerepel egy adaptív csúszómódállapotmegfigyelő kidolgozása a rotorellenállás becslésével, illetve a csúszómód-állapotbecslő gyakorlati alkalmazása a dSpace ${ }^{\circledR}$ valós idejü fejlesztési környezetben.

\section{Szakirodalmi hivatkozások}

[1] Picardi, C.; Scibilia, F.: Sliding-Mode Observer with Resistances or Speed Adaptation for Field-Oriented Induction Motor Drives. IECON 2006- $32^{\text {nd }}$ Annual Conference on IEEE Industrial Electronics, pp. 1481-1486.

[2]Kelemen, Árpád; Imecs, Mária: Vector Control of AC Drives, Vol. 1: Vector Control of Induction Machine Drives, OMIKKPublisher, Budapest, 1991. ISBN 963593 1409.

[3]Kelemen, Árpád; Imecs, Mária: Sisteme de reglare cu orientare după cîmp a mașinilor de curent alternativ. Editura Academiei Române, București, 1989. 
[4] Bemporad, A.: Automatic Control- State Estimation and Linear Observers. Lecture, University of Trento, Academic year 20102011.
[5] Bühler, H.: Réglage par mode de glissementComplément au traité d'électricité. Presses Polytechniques Romandes, Lausanne, 1986. 